\title{
SEDIAAN NANOPARTIKEL KITOSAN EKSTRAK IKAN GABUS (CHANNA STRIATA) DAN UJI AKTIVITAS ALBUMIN TERHADAP PENYEMBUHAN LUKA PASCA PENCABUTAN GIGI
}

\author{
Naning K Utami ${ }^{1}$, Metty Amperawati ${ }^{2}$
}

\author{
IDosen Poltekkes Kemenkes Banjarmasin Jurusan Keperawatan Gigi, email: \\ kunaning82@gmail.com \\ 2Dosen Poltekkes Kemenkes Banjarmasin Jurusan Keperawatan Gigi, email: \\ mettyampera@gmail.com
}

\section{ABSTRAK}

Ikan gabus (Channa striatus) banyak ditemukan di wilayah perairan sungai di Kalimantan Selatan. Ikan Gabus memiliki kadar protein yang lebih tinggi. Penelitian yang dilakukan Utami, N.K dan Amperawati,M., (2017), mengatakan bahwa ekstrak gel ikan gabus lebih baik dibandingkan ekstrak gel ikan kembung, karena penutupan luka pasca pencabutan gigi pada tikus putih.

Tujuan umum penelitian ini adalah Untuk mengetahui Sediaan Nanopartikel Kitosan Ekstrak Ikan Gabus (Channa Striata) dan Uji Aktivitas Albumin terhadap Penyembuhan Luka Pasca Pencabutan Gigi.sedangkan tujuan khususnya adalah untuk mengetahui: 1). Sediaan yang optimal berdasarkan perbandingan kitosan dengan ekstrak, perbandingan tripolifosfat yang digunakan, dan perbedaan $\mathrm{pH}$ dapar pada pelarutan kitosan, 2). Karakter fisik dari nanopartikel ekstrak ikan gabus dan 3). Aktivitas albumin nanopartikel ekstrak terhadap Penyembuhan Luka Pasca Pencabutan Gigi.

Metode penelitiannya eksperimental, penelitian dengan cara menguji nanopartikel ikan gabus terhadap penyembuhan luka pasca pencabutan gigi yang terbagi 2 (dua) kelompok, yaitu kontrol dan perlakuan. Tempat penelitian di Klinik Asthma Center dan dilaboratorium Farmakologi. Pengambilan accidental sampling. Variabel terikat adalah penyembuhan luka, Variabel bebas adalah Nanopartikel Ikan Gabus. Alat dan bahan yang digunakan alat pencabutan gigi di klinik Asthma Center dan sediaan nanopartikel.

Hasil uji statistik menunjukan bahwa aktivitas albumin nanopartikel kitosan ekstrak ikan haruan terhadap penyembuhan luka pasca pencabutan gigi lebih cepat dibandingkan dengan yang tanpa perlakuan. Disarankan Formulasi sediaan nanopartikel ekstrak ikan haruan dapat dibuat dalam bentuk obat kumur-kumur, variasi rasa, dan variasi konsentrasi.

Kata Kunci: Nanopartikel Kitosan Ikan haruan, Albumin, Penyembuhan luka 


\title{
ABSTRACT \\ Chitosan Nanoparticles Preparation of Cork Fish ( Channa Striata) Extract and Albumin Activity Test for Healing of Post-Extraction Wounds
}

\author{
Naning K Utami ${ }^{1}$, Metty Amperawati ${ }^{2}$
}

\author{
${ }^{1}$ Lecturer at Polytechnic of Health of Ministry of Health Banjarmasin Majoring Dental \\ Nurse, E-Mail: kunaning82@gmail.com \\ ${ }^{2}$ Lecturer at Polytechnic of Health of Ministry of Health Banjarmasin Majoring Dental \\ Nurse, E-Mail: mettyampera@gmail.com
}

Cork fish (Channastriatus) are commonly found in river waters in South Kalimantan. Cork fish have higher protein content. Research conducted by Utami, N.K and Amperawati, M., (2017), said that cork fish gel extract was better than bloated fish gel extract, because of the closure of wounds after tooth extraction in white rats.

The general purpose of this study was to determine the preparation of chitosan nanoparticles of cork fish extract (Channa Striata) and albumin activity test for healing of postextraction wounds, while the specific purpose was to find out: 1). The optimal preparation based on the ratio of chitosan to extract, the ratio of tripolyphosphate used, and the difference in $\mathrm{pH}$ at the chitosan dissolution, 2). Physical characteristics of cork fish extract nanoparticles and 3). Nanoparticles extract activity of the album against the healing of post extraction wounds.

The research method is experimental, research by testing cork fish nanoparticles on wound healing after tooth extraction which is divided into 2 (two) groups, namely control and treatment. Research sites in the Asthma Center Clinic and in the Pharmacology laboratory. Taking accidental sampling. The dependent variable is wound healing, the independent variable is Cork Fish Nanoparticles. Tools and materials used for tooth extraction at the Asthma Center clinic and Nanoparticle preparations.

Statistical test results showed that the activity of chitosan nanoparticles albumin extract of cork fish on wound healing after tooth extraction was faster than those without treatment. It is recommended that the formulation of cork fish extract nanoparticles can be made in the form of mouthwash, variations in taste, and variations in concentration.

Keywords: Chitosan Nanoparticles Cork Fish, Albumin, Wound Healing

\section{PENDAHULUAN \\ Latar Belakang}

Ikan sebagai salah satu sumber protein hewani mengandung asam lemak tak jenuh (eicosapentaenoic acid/EPA, docosahexanoid acid/DHA), yodium, selenium, fluorida, zat besi, taurin, coenzyme Q10 dan kalori yang rendah (Harli., 2004).

Ikan haruan (Channa striatus) banyak ditemukan di wilayah perairan sungai di Kalimantan Selatan. Ikan Haruan memiliki kadar protein yang lebih tinggi dibandingkan dengan jenis ikan lainnya. Ikan haruan mengandung semua asam amino esensial yang dibutuhkan untuk menyembuhkan luka, antara lain arginin, glisin, lisin, prolin, glukosamin, asam D-glukoronat dan karnosin (Baie SH, Sheikh KA., 2000; Lay-Harn Gam, Chiuan-Yee Leow, Saringat Baie., 2005). Kandungan protein dan asam lemak dari daging ikan haruan inilah yang dimanfaatkan dalam penelitian ini sebagai zat aktif untuk penyembuhan luka.

Penelitian yang dilakukan oleh Rahmawanty, D, Anwar,E, Bahtiar, A., (2014), diperoleh hasil dari uji in vivo sediaan gel serbuk daging ikan haruan dapat digunakan sebagai penyembuh luka. Dan penelitian yang telah dilakukan oleh Utami, N.K dan Amperawati,M., (2017), diperoleh hasil bahwa ekstrak gel ikan haruan lebih baik dibandingkan ekstrak gel ikan kembung, karena penutupan luka pasca pencabutan gigi pada tikus putih, karena adanya kandungan albumin pada ikan haruan. Albumin adalah merupakan suatu protein yang paling 
banyak terkandung di dalam plasma, lebih kurang 60\% dari total plasma.. Albumin salah satu jenis protein penting yang sangat bermanfaat untuk proses penyembuhan.

Pembuatan serbuk ikan haruan, yaitu dalam pembuatan serbuk ikan haruan ada halhal penting yang harus diperhatikan dalam adalah kualitas daging ikan haruan, ukuran potongan daging dan suhu. Ikan haruan yang telah dipotong-potong digiling, kemudian ditambahkan dengan pelarut etanol $70 \%$ dan diaduk selama 2 jam. Selanjutnya disaring dan dikumpulkan ampas untuk dikeringkan menggunakan freeze dryer. Hasil freeze dry kemudian dihancurkan dan diayak sehingga diperoleh serbuk konsentrat protein ikan haruan yang telah dikarakterisasi kandungannya. Ikan haruan sebagai bahan baku pembuatan serbuk haruan harus mempunyai kualitas yang baik, jika memungkinkan berasal dari yang masih hidup atau belum mengalami proses rigor ( Rahayu, 1992).

Nanopartikel dalam bidang farmasi merupakan suatu senyawa obat dengan cara tertentu dibuat berukuran nanometer yang disebut nanokristal atau senyawa obat dienkapsulasi dalam suatu sistem pembawa tertentu berukuran nanometer disebut nanocarrier (Abdassah, 2012). Kitosan adalah polimer alami jenis polisakarida yang diperoleh dari deasetilasi dari kitin. Kitin ditemukan padan cangkang hewan famili Crutaceae (kepiting, udang, lobster), mikroorganisme, dan beberapa jamur (Sailaja et al., 2010).

Pencabutan gigi adalah salah satu prosedur bedah dalam kedokteran gigi yang bertujuan untuk mengeluarkan gigi dari dalam soketnya. Sedangkan proses penyembuhan luka adalah proses yang sangat dinamis dan kompleks untuk mencapai homeostasis dan integritas jaringan

\section{BAHAN DAN METODE}

Penelitian eksperimental, penelitian dilakukan dengan cara menguji nanopartikel ikan haruan terhadap penyembuhan luka pasca pencabutan gigi. Pasien yang telah dilakukan pencabutan gigi pada molar rahang bawah pada kelompok pertama tidak diberikan ulasan nanopartikel ikan haruan dan pada kelompok kedua diberikan ulasan nanopartikel ikan haruan dan ke dua kelompok dilakukan pengukuran luka dari hari ke-1 sampai ke-14.

Populasi dan Sampel Penelitian Pasien yang datang ke klinik Asthma Center Banjarbaru dengan indikasi pencabutan gigi molar rahang bawah, pengambilan sampel secara accidental sampling..

Teknik Pengambilan Data Teknik pengambilan data adalah data diperoleh dari data primer data yang diperoleh dengan melakukan pemeriksaan gigi dan sesuai dengan indikasi untuk dilakukan pencabutan gigi molar rahang bawah serta melakukan pengukuran, pencatatan dan pengolesan nanopartikel selama proses penyembuhan luka pasca pencabutan gigi setiap hari selama 14 hari.

Analisi Data Analisis data adalah setelah data diperoleh, dikumpulkan,diolah dan dianalisis kemudian data disajikan dalam bentuk frekuensi, tabel dan selanjutnya dianalisis.

\section{HASIL DAN PEMBAHASAN}

Hasil optimasi formulasi sediaan nanopartikel ekstrak ikan haruan menunjukkan perbandingan antara ekstrak:kitosan:tripolifosfat, yaitu 2:1:0,1 bagian dengan dapar asestat $\mathrm{pH} 4$ untuk melarutkan kitosan.

Karakterisasi dilakukan dengan menggunakan alat particlc size analyscr (PSA) dan transmition electron microscope (TEM) berdasarkan data dengan menggunakan mikrospok electron (TEM) menegakkan ukuran partikel berada dalam rentang nanopartikel (kurang dari $1000 \mathrm{~nm}$ ). Diperoleh hasil Karakteristik nanopartikel ekstrak ikan haruan yang didapat, yaitu ukuran partikel 110,4 $\mathrm{mm}$ dengan bentuk partikel bulat.

Responden penelitian adalah pasien yang berkunjung ke klinik Asthma Center Banjarbaru dengan indikasi pencabutan gigi geraham bawah. Dan pasien bersedia untuk menjadi responden dan kooperatif untuk melakukan pengukuran selama 14 hari. Sehingga diperoleh hasil sebagai berikut:

\footnotetext{
Tabel. 1. Pencabutan Gigi Geraham Bawah Tanpa Perlakukan Pemberian Sediaan Nanopartikel Kitosan Ekstrak Ikan Haruan (hari/mm) .
} 


\begin{tabular}{|c|c|c|c|c|c|c|c|c|c|c|c|c|c|c|c|}
\hline \multirow{2}{*}{$\begin{array}{l}\mathbf{N} \\
\mathbf{0}\end{array}$} & \multirow{2}{*}{$\begin{array}{c}\text { Respo } \\
n \\
\text { den }\end{array}$} & \multicolumn{14}{|c|}{ Hari } \\
\hline & & 1 & 2 & 3 & 4 & 5 & 6 & 7 & 8 & 9 & 10 & 11 & 12 & 13 & 14 \\
\hline 1 & $\mathrm{R} 1$ & 1,6 & $\begin{array}{l}1, \\
5\end{array}$ & $\begin{array}{l}1, \\
5\end{array}$ & $\begin{array}{l}1, \\
4\end{array}$ & $\begin{array}{l}1, \\
4\end{array}$ & $\begin{array}{l}1, \\
3\end{array}$ & $\begin{array}{l}1, \\
3\end{array}$ & $\begin{array}{l}1, \\
3\end{array}$ & $\begin{array}{l}1, \\
2\end{array}$ & 1.1 & 0,9 & 0,8 & 0,8 & 0,7 \\
\hline 2 & $\mathrm{R} 2$ & 1,0 & $\begin{array}{l}1, \\
0\end{array}$ & $\begin{array}{l}0, \\
9\end{array}$ & $\begin{array}{l}0, \\
9\end{array}$ & $\begin{array}{l}0, \\
8\end{array}$ & $\begin{array}{l}0, \\
8\end{array}$ & $\begin{array}{l}0, \\
8\end{array}$ & $\begin{array}{l}0, \\
8\end{array}$ & $\begin{array}{l}0, \\
8\end{array}$ & 0,8 & 0,8 & 0,7 & 0,7 & 0,7 \\
\hline 3 & R3 & 1,4 & $\begin{array}{l}1, \\
3\end{array}$ & $\begin{array}{l}1, \\
2\end{array}$ & $\begin{array}{l}1, \\
0\end{array}$ & $\begin{array}{l}0, \\
8\end{array}$ & $\begin{array}{l}0, \\
8\end{array}$ & $\begin{array}{l}0, \\
7\end{array}$ & $\begin{array}{l}0, \\
6\end{array}$ & $\begin{array}{l}0, \\
6\end{array}$ & 0,5 & 0,5 & 0,5 & 0,4 & 0,4 \\
\hline 4 & R4 & 1,5 & $\begin{array}{l}1, \\
3\end{array}$ & $\begin{array}{l}1, \\
0\end{array}$ & $\begin{array}{l}0, \\
9\end{array}$ & $\begin{array}{l}0, \\
8\end{array}$ & $\begin{array}{l}0, \\
8\end{array}$ & $\begin{array}{l}0, \\
8\end{array}$ & $\begin{array}{l}0 \\
8\end{array}$ & $\begin{array}{l}0, \\
8\end{array}$ & 0,8 & 0,7 & 0,7 & 0,7 & 0,6 \\
\hline
\end{tabular}

Sumber: Data Primer

Tabel.1. Nampak R1 hari $1=1,6 \mathrm{~mm}$ dan hari $14=0,7$, R2 hari $1=1,0 \mathrm{~mm}$ dan hari $14=0,7$ $\mathrm{mm}$, dan $\mathrm{R} 3$ hari $1=1,4 \mathrm{~mm}$ dan hari $14=0,4 \mathrm{~mm}$, sedangkan $\mathrm{R} 4$ hari $1=1,5 \mathrm{~mm}$ dan hari $1=-0,6 \mathrm{~mm}$

Tabel.2. Pencabutan Gigi Geraham Bawah dengan Perlakukan Pemberian Sediaan Nanopartikel Kitosan Ekstrak Ikan Haruan (hari/mm).

\begin{tabular}{|c|c|c|c|c|c|c|c|c|c|c|c|c|c|c|c|}
\hline \multirow{2}{*}{$\begin{array}{l}\mathbf{N} \\
\mathbf{0}\end{array}$} & \multirow{2}{*}{$\begin{array}{c}\text { Respo } \\
\mathbf{n} \\
\text { den }\end{array}$} & \multicolumn{14}{|c|}{ Hari } \\
\hline & & 1 & 2 & 3 & 4 & 5 & 6 & 7 & 8 & 9 & 10 & 11 & 12 & 13 & 14 \\
\hline 1 & $\mathrm{R} 1$ & 1,4 & $\begin{array}{l}1, \\
2\end{array}$ & $\begin{array}{l}1 . \\
0\end{array}$ & $\begin{array}{l}0, \\
8\end{array}$ & $\begin{array}{l}0, \\
4\end{array}$ & $\begin{array}{l}0, \\
4\end{array}$ & $\begin{array}{l}0, \\
4\end{array}$ & $\begin{array}{l}0, \\
3\end{array}$ & $\begin{array}{l}0, \\
3\end{array}$ & 0,3 & 0,2 & 0,2 & 0,1 & 0,0 \\
\hline 2 & $\mathrm{R} 2$ & 1,4 & $\begin{array}{l}1, \\
2\end{array}$ & $\begin{array}{l}1, \\
0\end{array}$ & $\begin{array}{l}0, \\
8\end{array}$ & $\begin{array}{l}0, \\
7\end{array}$ & $\begin{array}{l}0, \\
7\end{array}$ & $\begin{array}{l}0, \\
6\end{array}$ & $\begin{array}{l}0, \\
6\end{array}$ & $\begin{array}{l}0 \\
5\end{array}$ & 0,4 & 0,3 & 0,2 & 0,2 & 0,1 \\
\hline 3 & R3 & 1,0 & $\begin{array}{l}0, \\
8\end{array}$ & $\begin{array}{l}0, \\
7\end{array}$ & $\begin{array}{l}0, \\
6\end{array}$ & $\begin{array}{l}0, \\
6\end{array}$ & $\begin{array}{l}0, \\
4\end{array}$ & $\begin{array}{l}0, \\
3\end{array}$ & $\begin{array}{l}0, \\
3\end{array}$ & $\begin{array}{l}0, \\
2\end{array}$ & 0,2 & 0,1 & 0,1 & 0,0 & 0,0 \\
\hline 4 & R4 & 1,0 & $\begin{array}{l}0, \\
8\end{array}$ & $\begin{array}{l}0, \\
8\end{array}$ & $\begin{array}{l}0, \\
6\end{array}$ & $\begin{array}{l}0, \\
6\end{array}$ & $\begin{array}{l}0, \\
5\end{array}$ & $\begin{array}{l}0, \\
5\end{array}$ & $\begin{array}{l}0, \\
4\end{array}$ & $\begin{array}{l}0, \\
4\end{array}$ & 0,3 & 0,3 & 0,2 & 0,1 & 0,0 \\
\hline
\end{tabular}

Sumber: Data Primer

Tabel. 2. Nampak R1 hari $1=1,4 \mathrm{~mm}$ dan hari $14=0,0 \mathrm{~mm}$, R2 hari $1=1,4 \mathrm{~mm}$ dan hari $14=0,1$ $\mathrm{mm}$, dan R3 hari $1=1,0 \mathrm{~mm}$ dan hari $14=0,0 \mathrm{~mm}$, sedangkan $\mathrm{R} 4$ hari $1=1,0 \mathrm{~mm}$ dan hari $1=-0,0 \mathrm{~mm}$.

Analisis statistik menggunakan Uji One Way Anova :

1. Pencabutan Gigi Geraham Bawah dengan Tanpa Perlakuan Sediaan Nanopartikel Kitosan Ekstrak Ikan Haruan.

Tabel.3. Test of Homogeneity of Variances pada Responden yang Dilakukan Pencabutan Gigi tanpa Perlakuan.

$\begin{array}{llll}\text { Levene Statistic } & \text { df1 } & \text { df2 } & \text { Sig. }\end{array}$

$\begin{array}{llll}5.049 & 3 & 52 & .004\end{array}$

Karena nilai $p=0,004<\alpha=0,05$ maka $\mathrm{H}_{0}$ ditolak atau keempat sampel mempunyai varians yang tidak sama, sehingga salah satu asumsi Anova tidak terpenuhi (yang seharusnya varians sampel sama).

Tabel.4. Tests of Normality 


\begin{tabular}{|c|c|c|c|c|c|c|}
\hline & Statistic & $\mathrm{df}$ & Sig. & Statistic & df & Sig. \\
\hline $\begin{array}{l}\text { Cabut GG Graham } \\
\text { bawah Non PL }\end{array}$ & 235 & 56 & .000 & .915 & 56 & .001 \\
\hline
\end{tabular}

Lilliefors Significance Correction

Hasil analisis Uji Normalitas nilai $p=0,000<\alpha=0,05$ maka sampel ini juga tidak normal, sehingga adanya 2 asumsi yang tidak terpenuhi tersebut maka uji statistik digunakan Uji Kruskel-Wallis sebagai berikut :

Hypthesis Test Summary

\begin{tabular}{|c|c|c|c|c|}
\hline & Null Hypothe:=i: & $T e=t$ & Sig. & ㅁこ: \\
\hline 1 & 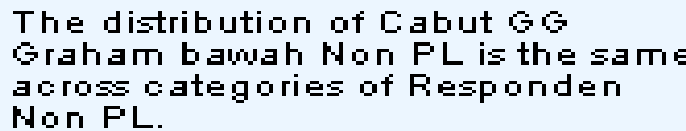 & $\begin{array}{l}\text { Inidependent- } \\
\text { eSamples } \\
\text { Krugkal- } \\
\text { injallis Test }\end{array}$ & . & $\begin{array}{l}\text { Fiejeot the } \\
\text { nuil } \\
\text { hypothesis. }\end{array}$ \\
\hline
\end{tabular}

Asymptotic significances are displayed. The significance level is Do.

Hasil ini menunjukkan bahwa nilai $p=0,002<\alpha=0,05$ maka $\mathrm{H}_{0}$ ditolak, artinya ada perbedaan sampel pada pencabutan gigi geraham bawah dengan tanpa perlakuan sediaan nanopartikel kitosan ekstrak ikan haruan terhadap penyembuhan luka pasca pencabutan gigi Nampak dalam grafik di bawah ini bawah, hasil mean plot menunjukkan bahwa sampel nomor.3 mempunyai pembukaan luka pada nilai yang terkecil, setelah dilakukan pengukuran pada hari ke-14.

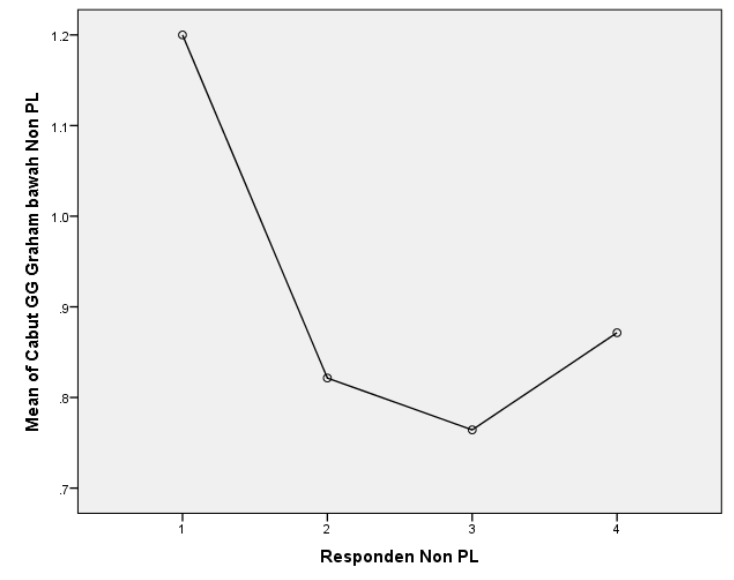

Gambar.3. Grafik Hasil Pencabutan Gigi tanpa Perlakuan

\section{Pencabutan Gigi Geraham Bawah dengan Perlakuan Sediaan Nanopartikel Kitosan Ekstrak Ikan Haruan.}

Tabel. 6. Test of Homogeneity of Variances pada Responden yang Dilakukan Pencabutan Gigi dengan Perlakuan.

\begin{tabular}{cccc}
\hline Levene Statistic & df1 & df2 & Sig. \\
\hline 920 & 3 & 52 & .438
\end{tabular}

Karena nilai $p=0,438>\alpha=0,05$ maka $\mathrm{H}_{0}$ diterima atau ke-empat sampel mempunyai varians yang sama, sehingga salah satu asumsi Anova terpenuhi. Oleh sebab itu dapat lanjut ke uji Anova, seperti dibawah ini.

Tabel. 7. Uji Anova 


\begin{tabular}{lrrrrr}
\hline & $\begin{array}{c}\text { Sum of } \\
\text { Squares }\end{array}$ & df & \multicolumn{1}{c}{$\begin{array}{c}\text { Mean } \\
\text { Square }\end{array}$} & F & Sig. \\
\hline Between Groups & .426 & 3 & .142 & 1.116 & .351 \\
Within Groups & 6.619 & 52 & .127 & & \\
Total & 7.046 & 55 & & & \\
\hline
\end{tabular}

Setelah dilanjutkan pada uji Anova maka nilai $\mathrm{p}=0,351>\alpha=0,05$ maka $\mathrm{H}_{0}$ diterima, artinya tidak ada perbedaan yang signifikan antara ke-empat sampel (Pencabutan gigi geraham bawah dengan perlakuan sediaan nanopartikel kitosan ekstrak ikan haruan) terhadap penyembuhan luka pasca pencabutan gigi.

Nampak dalam grafik di bawah ini bawah, hasil mean plot menunjukkan bahwa sampel nomor.3 mempunyai pembukaan luka pada nilai yang terkecil, setelah dilakukan pengukuran pada hari ke-14.

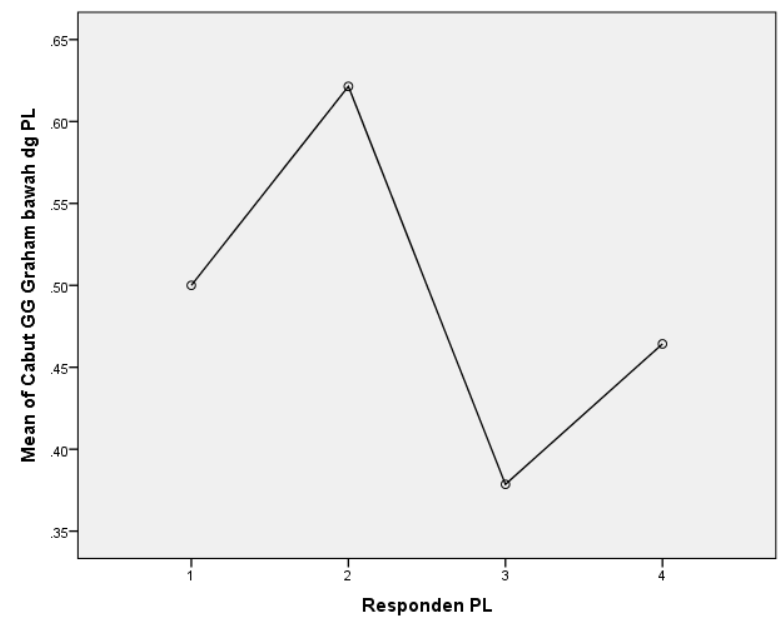

Gambar. 4.Grafik Hasil Pencabutan Gigi dengan Perlakuan

\section{Analisis Statistik Deskriptif.}

Statistik Deskriptif pada data yang berhasil dikumpulkan antara lain :

Tabel.5.8. Hasil Statistics

\begin{tabular}{lcc}
\hline & $\begin{array}{c}\text { Cabut GG Graham bawah } \\
\text { Non PL }\end{array}$ & $\begin{array}{c}\text { Cabut GG Graham bawah } \\
\text { dg PL }\end{array}$ \\
\hline $\mathrm{N} \quad$ Valid $\quad$ Missing & 56 & 56 \\
Mean & 0 & 0 \\
Median & .914 & .491 \\
Mode & .800 & .400 \\
Std. Deviation & .8 & .3 \\
Range & .3048 & .3579 \\
Minimum & 1.2 & 1.4 \\
Maximum & .4 & .0 \\
\hline
\end{tabular}

Hasil ini menunjukkan bahwa :

a. Rata-rata lebar luka pada dengan perlakuan lebih kecil dari pada non-perlakuan.

b. Nilai terendah (minimum) dengan perlakuan juga lebih kecil dibandingkan non-perlakuan.

\section{PEMBAHASAN}

Pada Hasil penelitian 1 dan 2 diperoleh nanopartikel ekstrak haruan yang didapat kemudian akan dikarakterisasi untuk memastikan terbentuknya ekstrak dalam ukuran nanopartikel, diperoleh ukuran partikel 110,4 nm, bentuk partikel bulat. Dimana Nanopartikel adalah partikel berukuran 1-100 nanometer dan kebanyakan metode menyarankan sebaiknya ukuran diameter partikel antara 200 dan 400 nm (Rachmawati, 2007). 
Ukuran partikel dari suspensi serbuk daging ikan haruan dengan kitosan tripolifosfat masih berada dibawah $1000 \mathrm{~nm}$ dengan demikian suspensi serbuk ikan haruan yang diperoleh dengan metode gelasi ionik yang menggunakan kitosan memiliki ukuran nanopartikel untuk formula.

Beberapa kelebihan nanopartikel adalah kemampuan untuk menembus ruangruang antar sel yang dapat ditembus oleh partikel koloidal. Selain itu, nanopartikel fleksibel untuk dikombinasikan dengan berbagai teknologi lain. Kemampuan ini membuka potensi luas untuk dikembangkan pada berbagai keperluan dan target. Kelebihan lain adalah adanya peningkatan afinitas dari sistem karena peningkatan luas permukaan kontak pada jumlah yang sama (Buzea et al., 2007).

Pada tabel. 5.1 dan .5.5. Hasil penelitian ini menunjukkan bahwa nilai $p=0,002<\alpha=0,05$ maka $\mathrm{H}_{0}$ ditolak, artinya ada perbedaan sampel pada pencabutan gigi geraham bawah dengan tanpa perlakuan sediaan nanopartikel kitosan ekstrak ikan haruan terhadap penyembuhan luka pasca pencabutan gigi. Hal ini didapatkann dari hasil pengukuran terhadap penyembuhan luka sudah mengalami penutupan walaupun sampai hari ke-14 masih belum tertutup dengan sempurna oleh jaringan granulasi.

Hal ini sesuai teori dalam penelitian Tungadi R,Attamimi,F, Sabu,E,F dkk (2011), dimana tingkat penyembuhan luka masih membutuhkan waktu 7-14 hari. Jaringan granulasi akan baru mulai terbentuk yang disusun oleh sel-sel darah merah, sel limfosit dan fibroblast. Selain itu hasil penelitian ini sesuai dengan teori Hidayat (2008), yang mengatakan bahwa pada hari ke-7 dimana pada fase ini adalah merupakan fase proliferasi, yang ditandai dengan luka sudah tidak mengeluarkan cairan/darah, terjadinya granulasi, terbentuknya jaringan kolagen yang menutup permukaan luka.

Tabel.5.2 dan 5.6. Hasil penelitian ini menunjukkan adanya nilai $p=0,438>\alpha=0,05$ maka $\mathrm{H}_{0}$ diterima atau ke-empat sampel mempunyai varians yang sama, hal ini dikarenakan percepatan penyembuhan luka hampir semuanya tertutup dengan sempurna pada hari ke-14 oleh jaringan baru. Hal ini dikarenakan ikan haruan mempunyai protein yang sangat tinggi, ini sesuai dengan Sediaoetama, (1985), yang mengatakan bahwa ikan haruan mempunyai senyawa yang sangat penting untuk tubuh, seperti protein dan mineral.

Berdasarkan tabel.5.8. Hasil uji menunjukkan bahwa secara statistis rata-rata lebar luka pada dengan perlakuan lebih kecil dari pada non-perlakuan, akan tetapi nilai terendah (minimum) dengan perlakuan juga lebih kecil dibandingkan non-perlakuan. Secara klinis bahwa rata-rata percepatan penyembuhan luka Pada ke-4 sampel yang tidak diberikan perlakuan pada hari ke- 14 masih ada cela luka pasca pencabutan gigi, sedangkan pada ke4 sampel pada kelompok perlakuan diperoleh rata-rata percepatan penyembuhan luka lebih cepat dengan pemberian sediaan nanopartikel kitosan eskstrak ikan haruan dimana dari ke4 sampel pada hari ke-14 luka sudah menutup dengan sempurna oleh jaringan granulasi.

Hal ini sesuai dengan penelitian yang dilakukan oleh Suprayitno,E (2003), yang mengatakan bahwa ikan haruan sangat kaya sumber albumin yang merupakan salah satu jenis protein yang dibutuhkan oleh manusia. Dimana albumin digunakan oleh penderita yang mengalami luka bakar dan wanita yang habis melahirkandianjurkan untuk mengkonsumsi ikan haruan untuk mempercepat proses penyembuhan.

Penelitian lainnya melaporkan bahwa konsumsi ekstrak ikan haruan dalam diet secara nyata dapat meningkatkan kadar albumin serum dan mempercepat proses penyembuhan luka setelah operasi (Aisyatusoffi dan Abdulgani 2013).

\section{KESIMPULAN}

1. Hasil optimasi formulasi sediaan nanopartikel ekstrak ikan haruan menunjukkan perbandingan antara ekstrak:kitosan:tripolifosfat, yaitu 2:1:0,1 bagian dengan dapar asestat $\mathrm{pH} 4$ untuk melarutkan kitosan.

2. Karakteristik nanopartikel ekstrak ikan haruan yang didapat, yaitu ukuran partikel 110,4 $\mathrm{mm}$ dengan bentuk partikel bulat.

3. Hasil uji statistik menunjukan bahwa aktivitas albumin nanopartikel kitosan ekstrak ikan haruan terhadap penyembuhan luka pasca pencabutan gigi lebih cepat dibandingkan 
dengan yang tanpa perlakuan. Dimana yang diberikan sediaan nanopartikel kitosan ekstrak ikan haruan pada hari ke-14 sudah tertutup oleh jaringan granulasi dengan sempurna.

\section{SARAN}

1. Formulasi sediaan nanopartikel ekstrak ikan haruan diharapkan bisa dibuat dalam bentuk variasi rasa, variasi konsentrasi dan obat kumur-kumur.

2. Selain untuk melihat jaringan granulasi sebaiknya dapat juga ditambahkan variabel lamanya waktu penyembuhan luka pasca pencabutan gigi.

\section{DAFTAR PUSTAKA}

Abdassah, 2012, Nanopartikel dengan Gelasi lonik. Farmaka. 15(1): 45-52

Allen, DL., 1980, Periodontics for the dental hygienist, 3 rd ed Philadelpia.

Atsari, F., 2014, Ketebalan Serabut Kolagen Pada Proses Penyembuhan Luka Pasca Ekstraksi Gigi Marmut (Cavia Cobaya) Setelah Pemberian Gel Ekstrak Teripang (Stichopus Noctivagus) 75\%, Universitas Gadjah Mada, Yogyakarta

Astawan, M. Teknik ekstraksi dan pemanfaatan minyak ikan untuk kesehatan. Buletin Teknologi dan Industri Pangan. 1998; 9(1): 44-51

Berger J, Reist M, Mayer, JM, Felt O, Peppas N.A, Gurny, R. Structure and interactions in covalently and ionically crosslinked chitosan hydrogels for biomedical application. Eur. J. Pharm. Biopharm.2004. 57:19-34.

Baie SH and Sheikh KA., 2000, The wound healing properties of Channa striatus-cetrimide cream-wound contraction and glycosaminoglycan measurement. Journal of

Dahuri,2012 Ethnopharmacology. 2000. 73:15-30.

Depkes, RI.,2000,

Fabregas A, Minarro M, Montoya E, Lozano P, Carrillo C, Sarrate R, et al. Impact of physical parameters on particle size and reaction yield when using the ionic gelation method to obtain cationic polymeric chitosan- tripolyphosphate nanoparticles. International Journal of Pharmaceutics. 2013. 446:199-204.

Ghufran M. 2010. A to Z Budidaya Biota Akuatik untuk Pangan, Kosmetik dan Obat-obatan. Yogyakarta (ID): Penerbit ANDI.

Harli, 2004,

Hidayat,A., 2008, Ketrampilan Dasar Praktik Klinik Untuk kebidanan. Jakarta: Salemba Medika.

Lay-Harn Gam, Chiuan-Yee Leow, Saringat Baie., 2005, Amino acid composition of snakehead fish (Channa striatus) of various sizes obtained at different times of the year. Malaysian Journal of Pharmaceutical Sciences. 2005.3(2): 19-30.

Ida A, soelistiono, prihartiningsi, Pengaruh ekstrak batang salvadora persica terhadap pertumbuhan bakteri streptococcus hasil isolasi paska pencabutan gigi molar ketiga mandibular. Jurnal bagian ilmu bedah mulut FKG UGM 2008;1.Available from : http://idaayu.files.wordpress.com/paper01.p

Mathur,Vyaas.,2013,

Mohanraj and Chen, 2006, Nanoparticles - A Review, Trop J Pharm Res, June 2006; 5 (1) : 561-573,

Notoatmodjo, 1993, Metodologi Penelitian Kesehatan, Rineke Cipta, Jakarta

Pati F, Adhikari B, Dhara S. Development of chitosan- tripolyphosphate fibers through pH dependent ionotropic gelation. Carbohydrate Research. 2011.346:2582-88

Rahayu W, P,. S. Maamoen,. Suliantari, dan S. Fardiaz. 1992. Teknologi Fermentasi Produk Perikanan . Bogor (ID): Penerbit Pusat antar Universitas Pangan dan Gizi, Institut Pertanian Bogor.

Rahmawanty,D, Anwar,E, Bahtiar,A., 2014, Formulasi Gel Menggunakan Serbuk Daging Ikan Haruan (Channa Striatus) Sebagai Penyembuh Luka, Media Farmasi, Vol.11 No.1Maret $2014: 29-40$

Ronny., 2011 
Ranjit and Baquee, 2013, Nanoparticle: an Overview of Prepation, Characterization and Application. Int. Res. J. Pharm, 2013, 4(4).

Safriani,K.,2014, Perbedaan Lamanya Penyembuhan Pasca Pencabutan Gigi Antara Perokok dan Bukan Perokok,Universitas Hasanuddin, Makassar.

Sailaja, A. Amareshwar, P. and Chakravarty, P. 2010. Chitosan Nanoparticles as a Drug Delivery System. RJPBCS, Volume 1 Issue 3 Page No. 474.

Sediaoetama,A,D.,1985, Imu Gizi Jilid II, Jakarta:Dian Rakyat.

Sundar, S., Kundu, J., dan Kundu, S., 2010, Biopolymeric nnanoparticles, Sci. Technol. Adv. Mater.11(2010) 014104 (13pp)

Suprayitno,E.,2003, Albumin Ikan Haruan (Ophiocephaluas Striatus) sebagai makanan fungsional mengatasi gizi masa depan. http://www.antarajatim.com (30 oktober 2008)

Suprapti, L. 2008. Teknologi Pengolahan Pangan: Produk Olahan Ikan. Yogyakarta (ID). KANISIUS

Shepherd, R., Reader, S., and Falshaw, A., 1997, Chitosan Functional Properties, Glycoconjugate Journal (1997) 14: 535 Đ 542

Utami,N.K, Amperawati,M.,2017, Ekstrak Gel Ikan Haruan dan Ikan Kembung terhadap Penyembuhan Luka Pasca Pencabutan Gigi Tikus Putih

Tungadi,R,Attamimi,F,Sabu,E,F dkk.,(2011), Percepatan Penyembuhan Luka Oleh Krim Ikan Haruan (Ophiocephaluas Striatus) terhadap Luka Kulit Kelinci Secara Histopatologi

Thassu, D., Deleers, M., Pathak, Y., 2007, Nanoparticulate Drug Delivery Systems, Informa Healthcare USA, New York.

Tiyaboonchai, W., 2003, Chitosan Nanoparticles : A Promising System for Drug Delivery, Naresuan University Journal 2003; 11(3): 51-66.

Trinanda, V, 2015, 